\title{
Gods Are Still in Business - Introduction to the Symposium: God and Management
}

\section{Marian Eabrasu ${ }^{1}$}

Published online: 25 October 2019

(C) Springer Nature Switzerland AG 2019

The relationship between God and management is mostly discussed in terms of the application of religious principles and virtues to business. This is regularly covered by studies in various areas of business ethics, leadership, and human resources, but little has been done to study the implications for management of the wide variety of theological, ontological, metaphysical, and epistemological perspectives on God. This is precisely the theoretical gap the symposium "God and Management" aims to reduce by contributing to a corpus of literature parallel to mainstream discussions of embedding spirituality and faith in business ethics. The authors of the articles in this symposium propose to take a step back from the practical implications of faith in business, with the aim of presenting a more general and abstract understanding of the philosophical and theological implications of religion in management. The key questions formulated in the call for papers made by Mark Dibben and Graham K. Henning for the 2017 Philosophy of Mangement Conference were: What role does God play in a managerial choice? If there is a role, what are its influences on or what is its confluence with the managerial choice? Is God's existence essential or relevant to management? The articles selected are intended to stimulate discussions about theism, its meaning, and influences on management theories and practices.

At the outset, a key issue at stake is the very definition of God. A classic proposed definition is Tillich's idea that God is the "ultimate concern" of an individual. That being said, this formula remains notoriously ambiguous (Rowe 1968), and Tillich himself seems to hesitate between two distinct interpretations: "The word 'concern' points to two sides of a relationship, the relation between the one who is concerned and his concern. In both respects, we have to imagine man's situation in itself and in his world" (Tillich 1957, pp. 8-9). One aspect of this relationship concerns the individual's subjective expectations and personal attitudes towards the object of devotion: "faith is a total and centered act of the personal self, the act of unconditional, infinite and ultimate concern" (Tillich 1957, p. 8). The other aspect refers to the ontological status of attitudes towards the object of devotion: "the unconditional concern which is faith is the concern about the unconditional" (Tillich 1957, p. 9).

Marian Eabrasu

eabrasu@yahoo.com 
Moreover, in conceiving God as the "ultimate concern", Tillich implicitly generates a complex debate over God's manifestations (Rowe 1962; Leftow 1990). In most religions, God is a passive object of the love and gratitude of believers, but also carries high expectations as believers praise, supplicate, confess, ask forgiveness and hope for a reponse. However, in other religions, such as Theravada, Buddhism (Jones 1979), and Daoism (Hennig 2017a, 2017 b), the "ultimate concern" mostly identifies God with the objective of a lifetime quest that should transform humans by reaching the good through union with God.

At any rate, it is mostly agreed that Tillich's interpretation of God is particularly inclusive, although it can easily be added that it may be too inclusive (Spiro 1966). Indeed, this definition of faith can be accommodated alongside not only classical religious beliefs and various philosophical perspectives but also beliefs that most people would consider non-religious and even anti-religious (Peltonen 2019). For instance, the "ultimate concern" can refer not only to religious people but also to atheists and agnostics; it can further apply to the blind conviction of a voter in a political party, or the irrational passion of supporters for their favourite sports team. More specifically, in business, the "ultimate concern" might also refer to a manager's devotion to an organization, or a consumer's fetishism for a product (Nicholas 2008). In a nutshell, this interpretation of God can be so broad that it could include nearly all interactions between individuals and abstract entities (organizations, states, societies, cultures, ideas) that go beyond a contractual relationship or a rational calculation of costs and benefits.

In reaction to Tillich's definition of God as the "ultimate concern" is a broad spectrum of interpretations of God, built in opposition to the patent limitations of humans. Within this perspective, God encompasses various human attributes that are turned towards perfection. For instance, God can be defined as the maximum extension of knowledge (compared with humans, God is omniscient), the maximum extension of behaviour (God is intrinsically good), the maximum physical presence in space and through time (God is omnipresent and eternal), and the maximum extension of power (God is omnipotent). Plantinga (1977, p. 108) formulates a particularly demanding conception of God since he includes not the only the actual world but all possible worlds: "A Being has maximal greatness in a given world only if it has maximal excellence in every world. A being has maximal excellence in a given world only if it has omniscience, omnipotence, and moral perfection in that world."

Assigning to God various attributes that are maximally great also has significant consequences for conceiving exchanges (including commercial ones) between less-than-perfect beings. For instance, the assumption that God is omniscient implies that God already knows all that the lessthan-perfect beings know individually and collectively. Moreover, if God not only discerns natural facts but can also have access to the most intimate expectations and the order of subjective preferences of less-than-perfect beings - and hence to their subjective scales of values and utility - then all business opportunities and future managerial choices and consumer preferences are already available to such a perfect being (Eabrasu 2011, p. 232). Furthermore, the assumption of an omnipotent God implies that God not only knows all business opportunities, managerial choices, and consumer preferences but can also create them. Further, we can add to these assumptions a specific ontological configuration admitting the possibility that the frontier between perfect and lessthan-perfect beings is porous. This can happen because there are degrees of perfection and the lessthan-perfect beings can improve and climb up the ladder of perfection, for instance, through prayer, meditation, or virtuous behaviour.

Within such a specific ontological construction (allowing less-than-perfect beings to have access to closer-to-perfection knowledge), faith might directly influence business activity, since it puts believers in a better position than non-believers by giving them straightforward access to business opportunities. The effects on business activities of this specific ontological 
arrangement (which encompasses a ladder of knowledge that matches religiosity) differ significantly from the mainstream approach, where faith influences business activity in a merely indirect manner, through business education (Epstein 2002) and through the specific behaviour of believers (Barnett and Karson 1987). For instance, based on in-depth interviews with twenty Dutch executives from different religious backgrounds, Graafland et al. (2007, p. 331) found "much inductive evidence of a relationship between their conception of God, norms, and values and business conduct". They also found that "executives with a monotheistic conception of God display a stronger orientation toward socially responsible business conduct than executives with a pantheistic conception of God". In other words, whereas the mainstream interpretation of faith in business ethics suggests that managers, employees, and consumers who believe in God are making different choices from non-believers, within an ontological arrangement that associates degrees of knowledge with degrees of faith, believers can know more about business opportunities (and hence make better choices) than nonbelievers. Without delving further into this discussion, it is important to note the diversity of ways in which a specific conception of God can influence business activity.

Nevertheless, the conception of God as being maximally great seems too restrictive in some regards, since it excludes the possibility of a limited deity. Several theological traditions allow interpretations of God as a limited being. Hence, there is a tendency to propose a more flexible interpretation of the definition of God, which could also include non-perfect attributes. At the theoretical level, several theological streams of thought oppose - more or less resolutely - the idea of God as maximal greatness. Classical theists such as neo-Thomists readily admit the possibility that part of God's omnipotence is the capacity to self-impose some limitations and to accept being affected by normal processes (Ford 1991). Also, "open theism dissents from the traditional consensus that God controls all things, but it refuses to give up the belief that could control all things if he so chose" (Highfield 2002p. 279). However, "process theism" imposes the most substantial challenge to this idea that God has perfect attributes. This stream of theological enquiry, grounded initially in the work of Whitehead and Hartshorne, goes beyond the idea that omnipotence supposes a discretionary capacity for self-limitation and further discusses the possibility and implications of an inherent limitation of God. Indeed, prominent scholars of process theism such as Whitehead and Hartshorne explicitly refer to the religious traditions that admit limited deities such as Buddist Nirvana (Johnson 1983). Despite the fact that process theism is far from a monolithic theory, since it encompasses several variants, it is nonetheless distinguished from other theological perspectives as it contests the necessity of deriving God's intangibility from perfection.

Notwithstanding noticeable differences among various streams of process theism, they all share the idea that God evolves within a temporal framework and is affected by these temporal processes. The difference from the neo-Thomistic idea of God's self-limitation is that process theism insists that non-perfect attributes are not the result of God's deliberate choice but are an essential and inherent feature of God. To be sure, this is not to say that God cannot have perfect attributes such as omniscience, omnipotence, omnipresence, eternity, and goodness. Process theism instead stresses that God might have non-perfect attributes. Its primary feature is a critique of the monopolarity of classical theism: the view that God can only be characterized by one side of a pair of oppositions. "One pole of each contrary is regarded as more excellent than the other, so that the supremely excellent being cannot be described by the other and inferior pole" (Hartshorne and Reese 1953, p. 2). It is precisely in reaction to this critique of monopolarity that Whitehead refers to entities as dipolar (Kraus 1998, pp. 52-53): having two poles - one physical and the other mental (Voskuil 2016). 
Within this theoretical framework laid down by Whitehead, Margaret R. DiMarco Allen's article "God, Ontology, and Management: A Philosophical Praxis" shows the impact of Whitehead's approach on management process theory and practice (Allen 2018). It traces the process concept in philosophy back to ancient Greece and discusses several features of "God as Poet, Ultimate Creativity and Connected", "God in Process" and "God of Hope and of Tragedy". DiMarco Allen sees two significant advantages in adopting this process theism conception of God compared with those available in classical or open theism. On one hand, process theism "reflects a resonating compatibility and logic that is not outside the realm of the natural; it can fit in with what one feels and observes" (Allen 2018). On the other, it "respects the validity of religious experiences throughout the totality of human history" (Allen 2018). Her argument in favour of using Whitehead's conception of God goes further, with the observation that it is "both independent and all-inclusive; God is both the primordial actuality, the ground of becoming for all that is, that which created the world and from which came the world; and God has an evolving consequent nature that is based on the experiences of the created natural world which exists within God" (Allen 2018).

That said, DiMarco Allen insists that despite it encompassing heterogeneous and apparently contrary features of God, "process philosophy does not equate into a soft (as in undisciplined, irresponsible, inconsequential) management style of unending positivity. Process is creative and open, and it is also specific and focused, with rules of action and reaction, cause and effect" (Allen 2018). Moreover, she concludes that "a God-oriented process philosophy of management strikes a balance that is both practical and spiritual, creating a safe environment for connection and creativity such that participation and collaboration in a community may occur, and ongoing learning, adaptation, and novel creativity may occur - all of which helps the individual and organization fulfill their purpose, and the universe as a whole grow in perfection, fullness, beauty, and harmony" (Allen 2018).

The role assigned to God in management in particular and in social sciences in general, by process theism but also by classical and open theism, might suggest that God is an important object of study. However, beside these specific discussions, the relationship between theology and social sciences (broadly understood) is far more complex. In fact, the approach of social sciences to God underwent a sizable transition between the nineteenth and twenty-first centuries (Young and Killick 2017). The prevalent positivism at the beginning of the nineteenth century led to the secularization of methods and theories throughout the twentieth century (Stark et al. 1996). Yet, starting in the late twentieth century, a gradually increasing interest in religion and the practical implications of faith on various areas of society spanning politics and business has emerged (Ebaugh 2002). Retrospectively, the thesis that religion has remained continuously anchored in society despite being relegated to the background of academic attention has gained momentum (Hammond 1985). That said, a key question is how to interpret theology's relationship to social sciences in general, and to management in particular.

Enrico Beltramini's article "God and Modernity in Management Studies: A Case of Theological Social Theory" focuses on Christian theology and on the controversy concerning the relationship between theology and social sciences (Beltramini 2018). More specifically he proposes to fine-tune the approach formulated by John Milbank, one of the founders of "radical orthodoxy" (Milbank et al. 1999), an Anglo-Catholic stream of thought within "constructive theology". Milbank famously holds that, since the social sciences are a product of modern secular ethos, they cannot offer global understanding or a comprehensive explanation of social facts. Moreover, Milbank (2008, p. xii) that "“the social' of sociology is itself an 
unreal, unhistorical and quasi-theological category". Within his radical orthodoxy perspective, Milbank's objective is not to bridge the gap between social sciences and theology - since he does not see any gap between them - but rather to propose a hierarchical relationship where theology can offer a superior social theory. He "argues against theologians who have allowed an autonomy to secular reason, and have thereby sought to position theology within an essentially atheistic social theory" (Brown 2004, p. 153).

Within this perspective, theology does not need to use social theories, since it can offer an exhaustive vision of reality, encompassing by itself all areas that are also covered by social sciences such as politics, society, and business. As Beltramini notes, "non-theological disciplines like sociology, and, analogously, management, maintain religious assumptions that may not be aligned with orthodox Christianity" (Beltramini 2018). In his paper in this issue, Beltrami addresses "the question about how theology and management are related, and how they should be, without risking the inherent consistency that such theoretical disciplines assume and reproduce" (Beltramini 2018). He argues for dialogue between theology and management, which should not compromise their own fundamental principles and methodologies. The article states that an important source of controversy in management studies is the secularization of God: "In fact, every incorporation of the deity into management theory, without embracing the supernatural ontological premise that comes with such a deity, ends up in some forms of assimilation of the transcendent into the immanent frame. This assimilation, in turn, ultimately results in the transformation of the forms of supernatural transcendence into forms of naturalized immanence" (Beltramini 2018).

This argument about dialogue without compromise between theology and management should inspire further consideration of whether it is possible to apply it to religions or contexts other than Christianity (Oppenheim 2017). For instance, this type of dialogue might become complex when applied to religions where God is immanent rather than transcendent, and more particularly to religions that display pantheistic (Harrison 2004) or non-theistic features (Levine 2013). Moreover, the dialogue outlined in this paper presupposes a secular society, as famously described by Taylor (2007). Unlike a religious society, where it is almost impossible not to believe in God, a secular society is one in which believing in God is merely a choice among many other options. While this distinction does not exhaust all the debates (such as those about what exactly it means to "have the option" to believe or not in God), it nonetheless sheds light on the fact that secularism does not exclude God, and that theism needs particular attention even in a secular age.

Moreover, this discussion can be prolonged outside the scope of Beltramini's article to see whether such dialogue remains possible outside this particular societal configuration. Consider, for instance, two radical alternatives to Taylor's secular age: on the one hand, a religious society where - according to Taylor's interpretation - believing in God is not a choice but an obligation; and on the other, an overtly anti-religious social, and even legal framework where, for instance, faith cannot be displayed in public, and hence also cannot occur in a business context. The spheres of theology and management would overlap, and one would be erased, subordinated, or reduced to the other. Within such an asymmetrical context, it is assuredly more challenging to imagine a dialogue that remains sincere and without compromise.

The law represents a key lever to manage the equilibrium between theology and management in society. The increasing occurrence of controversies involving faith in a business context illustrates the difficulty of finding an acceptable equilibrium. This lever becomes particularly crucial in contexts where the frontier between public and private spheres is somewhat permeable (Young and Killick 2017). While these spheres encompass 
heterogeneous and possibly dissenting social norms and personal expectations, a single legal framework is expected to codify them all. The recent prevalence - in the United States, for instance - of controversies about the role of faith in the workplace, or the extent to which an owner can use faith as a reason to refuse a client, precisely illustrates the complex challenges in finding an equilibrium between theology and management.

A specific type of asymmetrical relationship between management and theology is further discussed in the article "God is Greater: Believing in the Unseen and the Expansion of Management Responsibility", in which Muatasim Ismaeel addresses a particular concern that faith is overshadowed and eventually reduced to pure pecuniary decisions (Ismaeel 2018). More generally, the paper starts with the observation that there is a reductionist tendency in management theory and practice: "The history of modern management can be seen as a history of continuous reductions. By reductions, I mean narrowing the scope and considerations of managers' responsibilities. It started with reducing man to homo economicus and reducing his motives to maximizing selfish utility, whether it is customers' satisfaction or companies' profit maximization. The reduction continued with reducing complex social phenomena to certain quantitative indicators and excluding values and qualitative considerations from management decision-making. The reduction continues further by reducing the economic to the financial" (Ismaeel 2018).

Based on this observation, the article first holds that reductionism is not limited to management and argues that, more generally, it is an expression of modernism and is rooted in nineteenth-century positivism. It sets out that this positivistic approach to management not only overshadows value judgments and faith but also tends to replace them with a different value scale and to replace God as the object of faith and ultimate concern with mercantile items. This is also to say, as noted above, that the definition of God as ultimate concern makes it possible to include material objects and commercial preferences. "In addition to omniscience and omnipotence claims of modern scientific doctrine, money obtains a status of omnipresence since everything is measured by money and it occupies the consciousness of almost all humankind. Obvious expressions of these Religion-like characteristics of modernism are the utopian claims that associate the triumph of neo-liberalism like Fukuyama's End of History and the connotations of globalization as finality in management texts" (Ismaeel 2018).

That being said, Ismaeel proposes to reinterpret the relationship between human beings and God through the lenses of the "trusteeship paradigm" developed by Taha Abderrahmane. Trust (al amāna) refers to the idea that humans are expected to be trustworthy in the sense that they willingly need to accept the responsibility entrusted to them by God of doing good. The objective of this analysis is to show a way of overcoming reductionism and restoring the importance of faith in management.

The argument against reductionism proposed in this article can be further connected with the idea of considering God as a stakeholder (Schwartz 2006) and hence endowing God with rights, using the model of natural stakeholders such as trees (Starik 1995). However, the parallel between including categories of God and of nature among stakeholders has notable limitations. Calls to integrate nature among stakeholders are mostly motivated by protecting natural entities from destruction. In contrast, the call to consider God as a stakeholder is motivated not by fear of destruction but rather by piousness. In India, for instance, Hindu gods can receive court summonses to help resolve property disputes, as they are considered legal entities who can make their case through the trustees or managing board in charge of the temple in which they are worshipped (Lubin et al. 2010, pp. 198-199). 
Furthermore, as Schwartz (2006) points out, God can be interpreted as a stakeholder not only by those managers who intimately believe that God exists but also by those who consider that their business might affect those who believe that God exists. There are numerous recent examples of companies that have been confronted with difficult managerial choices when dealing with products and services that might offend the faith of specific groups of people. This raises another interesting question regarding the strategy to be adopted, especially in the context of widespread tension between believers of different religions. A crucial decision to be taken is whether a manager should make a religious bias explicit and target a specific category of clients, as with halal food products or Christian investment funds. Yet when we take into account trans-religious companies (companies operating across more than one religion), religious bias raises tensions nonetheless, and makes it nearly impossible to adopt an uncontroversial strategy. Consider, for instance, IKEA's decision to digitally remove all women from the 2012 catalogue it distributed in Saudi Arabia. Consider also Lidl's decision, when intending to sell religion-neutral Greek products in Muslim countries, to use for its packaging a picture of iconic Santorini churches with the Christian cross symbol digitally removed. The controversy generated by this marketing strategy illustrates managers' difficulty in setting aside religious circumstances in the contemporary world (Eabrasu 2018). Even when God is not explicitly considered a stakeholder, the fact that other stakeholders have religious views unavoidably makes God a de facto stakeholder.

These contemporary cases and numerous others spanning the history of business denote an intertwined relation of secular and religious values. As can be easily observed, this is rarely a win-win relationship; very often, it underlines tensions and trade-offs. A feature of the relationship between God and management, focusing more specifically on the methodology behind a decision-making process, is further explored in Muers and Burton's article "Can We Take the Religion out of Religious Decision-Making? The Case of Quaker Business Method" (Muers and Burton 2018). The authors focus on the challenges raised by transferring decisionmaking process from a religious to a secular context, with the aim of highlighting the sets of managerial and theological questions that such a transfer generates. The article uses the example of the "Quaker business method": a decision-making method born from and developed in a religious context, which tends to be exported to secular business contexts. "The 'Quaker business method' include the lack of voting, of confrontational debate and of other practices that emphasize differences of opinion; an intentional shared search for unity, which is not understood as compromise or consensus; contemporaneous agreement of minutes (especially minutes of decision) in the meetings at which the decisions are taken, with the expectation of shared ownership of the decisions thereafter; and the use of reflective silence in meetings" (Muers and Burton 2018).

While the authors conclude that this method facilitates secular appropriation, they nonetheless point out the limitations of such transfers and the issues that might arise. The Quaker business method "might plausibly be accepted by people who are committed to certain core theological claims, while also making it possible fully to acknowledge, and indeed to enter into a dialogue about, the successful use of a religious decision-making practice in secular contexts and by non-believers" (Muers and Burton 2018). When focusing on the challenges of such transfers, the authors note the asymmetry of power in organizational decision-making and how it might shape "the understandings of divine power within the religiously-based decisionmaking process" (Muers and Burton 2018). Indeed, when this method is transferred to a decision-making process where there are sizable asymmetries of power, it is unclear whether the method is sufficient to restore these powers to equilibrium. It is also particularly interesting 
to explore the application of this method to religions where the intermediaries between God and believers play an essential role in translating, interpreting, or codifying God's will (Young and Killick 2017). This would be especially relevant in contexts where clergy in various religions tend themselves to become managers of faith (Torry 2017) - and are sometimes even educated as managers (Duvall and Pinson 2000) - and more generally when they appear as role models and sources of inspiration (Sahota et al. 2016).

Furthermore, a way to extend this discussion of how faith drives managerial decisions is to address it from a different angle (Van Duzer 2010). If managers look towards God to learn about how they should use their supplies, God has the last word on the control of scarce resources. This relies on several critical assumptions: not only that God exists and is a stakeholder but also that God owns all the scarce resources, and is understood as having control in the last resort (Torry 2017). This includes not only corporate resources but also the human body; not only decision-making processes in business but also daily life choices (Tam 2013). Adopting this standpoint usually generates tensions between divine and human ownership that tend to be solved by numerous natural law scholars through subordination of the latter to the former (Arjoon 2010). "Locke's understanding of self-ownership is equivalent to a 'liberty to use' God's property, so 'natural rights' are a shorthand expression for indicating the permissions of the natural law" (Seagrave 2011, p. 712).

Moreover, not only Christian theologians and natural law scholars but also scholars working within other religious traditions emphasize the interest in following God's will when deciding the use of corporate resources, since God owns them in the last resort (Habachy 1962). Within this perspective, the legal owners are perceived as stewards, while the CEO and managers would be second-degree stewards in the sense that they care for the resources entrusted to them by the legal owners, who care for the resources entrusted to them by the spiritual owners (Block 1993). In Islam, for instance, "The guardianship of resources is described as Khalifah, or vicegerency, invested with or characterized by delegated authority from God. The CEO of a business enterprise can be regarded as the Khalifah who is accountable to the Almighty for his actions" (Wilson 2006, p. 115).

These thoughts raise an interesting question about whether this method can be used for state-owned companies in secular legal frameworks. In countries where religion permeates the public sphere and is at the core of political decision-making, managers have more substantial latitude in referring to God in support of their decisions. Of course, the legal framework also plays a vital role in regulating the religious margins of private enterprises. The corporate personhood debate in the US is symptomatic of this perspective. Saying that a company can have its own personality raises questions of whether a company can have faith and publicly display its religious values and/or contractually impose them on its stakeholders (employees, clients, etc.). This last set of questions, and the various discusseions piutlined in this introduction, largely illustrate the breadth of the spectrum of issues relating to God in management and the depth and complexity of the associated debates. While this series of articles addresses keynote issues on the relationship between God and management, it nonetheless leaves open and calls for a more in-depth discussion on many other issues, all equally crucial. This introduction to the symposium "God and Management" strives to give a glimpse of some of them.

Some readers may be surprised that the God and management relationship is addressed here mostly from the perspective of two major Abrahamic monotheisms: Christianity and Islam. Indeed, it is important to note that, while the call for papers avoided reference to any particular 
religions, most of the papers submitted were anchored in an explicit theological ground. This observation illustrates the difficulty of escaping from a specific religious paradigm when discussing God. On the other hand, since this series of papers mostly focuses on two significant monotheisms, the question of God and management needs to be further explored through the lenses of Judaism and other non-Abrahamic religious traditions (Dharmic, Iranian, indigenous, traditional, etc.), as well aso various new religious movements. Moreover, it would be interesting to apply these analyses to a broader and more heterogeneous variety of metaphysical, eschatological, and axiological systems.

Acknowledgements While I am authoring this editorial, the acknowledgment for issuing the call for papers and reviewing the papers should go to Mark Dibben and Graham K. Henning.

\section{References}

Allen, Margaret R.D. Imarco. 2018. God, Ontology and Management: A Philosophical Praxis. Philosophy of Management. https://doi.org/10.1007/s40926-018-0101-6.

Arjoon, Surendra. 2010. An Aristotelian-Thomistic approach to management practice. Philosophy of Management 9 (2): 47-64.

Barnett, John H., and Marvin J. Karson. 1987. Personal values and business decisions: An exploratory investigation. Journal of Business Ethics 6 (5): 371-382.

Beltramini, Enrico. 2018. God and modernity in management studies. A Case of Theological Social Theory. Philosophy of Management. https://doi.org/10.1007/s40926-018-0090-5.

Block, Peter. 1993. Stewardship: Choosing service over self-interest. Berrett-Koehler Publishers.

Brown, Malcolm. 2004. After the market: Economics, moral agreement and the Churches' Mission. Peter Lang.

Duvall, Cheryl King, and Kathleen B. Pinson. 2000. Role changes within the clergy: Theological and business education. Journal of Ministry Marketing \& Management 6 (2): 43-53.

Eabrasu, Marian. 2011. A Praxeological assessment of subjective value. Quarterly Journal of Austrian Economics 14 (2): 216-241.

Eabrasu, Marian. 2018. Moral disagreements in business. An exploratory introduction. Cham: Springer.

Ebaugh, Helen Rose. 2002. Return of the sacred: Reintegrating religion in the social sciences. Journal for the Scientific Study of Religion 41 (3): 385-395.

Epstein, Edwin M. 2002. Religion and business-the critical role of religious traditions in management education. Journal of Business Ethics 38 (1-2): 91-96.

Ford, Lewis S. 1991. Contrasting conceptions of creation. The Review of Metaphysics 45 (1): 89-109.

Graafland, Johan, Muel Kaptein, and Corrie Mazereeuw van der Duijn Schouten. 2007. Conceptions of god, normative convictions, and socially responsible business conduct: An explorative study among executives. Business \& Society 46 (3): 331-368.

Habachy, Saba. 1962. Property, right, and contract is Muslim law. Colum. L. Rev. 62: 450.

Hammond, Phillip E. 1985. The sacred in a secular age: Toward revision in the scientific study of religion. University of California Press.

Harrison, Paul. 2004. Elements of pantheism. Llumina Press.

Hartshorne, Charles, and William L. Reese. 1953. Philosophers speak of god. Chicago: University of Chicago Press.

Hennig, Alicia. 2017a. Applying Laozi's Dao De Jing in business. Philosophy of Management 16 (1): 19-33. https://doi.org/10.1007/s40926-016-0048-4.

Hennig, Alicia. 2017b. Daoism in Management. Philosophy of Management 16 (2): 161-182.

Highfield, Ron. 2002. The function of divine self-limitation in open theism: Great wall or picket fence? Journal of the Evangelical Theological Society 45 (2): 279.

Ismaeel, Muatasim. 2018. God is Greater: Believing in the Unseen and the Expansion of Management Responsibility. Philosophy of Management. https://doi.org/10.1007/s40926-018-0096-z.

Johnson, A.H. 1983. Some conversations with whitehead concerning god and creativity. In Explorations in Whitehead's philosophy, ed. Ford Lewis and George Kline, 3-13. New York: Fordham University Press.

Jones, Richard H. 1979. Theravāda Buddhism and morality. Journal of the American Academy of Religion 48 (3): 371-387. 
Kraus, Elizabeth M. 1998. The metaphysics of experience: A companion to Whitehead's process and reality. New York: Fordham Univ Press.

Leftow, Brian. 1990. Is god an abstract object? Noûs:581-598.

Levine, Michael. 2013. Non-theistic conceptions of God. In Routledge Companion to Philosophy of Religion, 294 -305. Routledge.

Lubin, Timothy, Donald R Davis Jr, And Jayanth K Krishnan. 2010. Hinduism and law: An introduction. Cambridge University Press.

Milbank, John. 2008. Theology and social theory: Beyond secular reason. John Wiley \& Sons.

Milbank, John, Catherine Pickstock, and Graham Ward. 1999. Radical orthodoxy: A new theology. Psychology Press.

Muers, Rachel, and Nicholas Burton. 2018. Can we take the religion out of religious decision-making? The Case of Quaker Business Method. Philosophy of Management. https://doi.org/10.1007/s40926-018-0095-0.

Nicholas, Jeffery. 2008. Eucharist and dragon fighting as resistance: Against commodity fetishism and scientism. Philosophy of Management 7 (1): 93-106. https://doi.org/10.5840/pom2008719.

Oppenheim, Lois Hecht. 2017. Enduring values for contemporary issues: Integrating Buddhist and Jewish morality into contemporary management models. Philosophy of Management 16 (1): 55-68.

Peltonen, Tuomo. 2019. Transcendence, Consciousness and Order: Towards a Philosophical Spirituality of Organization in the Footsteps of Plato and Eric Voegelin. Philosophy of Management. https://doi. org/10.1007/s40926-018-00105-6.

Plantinga, Alvin. 1977. God, freedom, and evil. Grand Rapids, Michigan: Wm. B. Eerdmans Publishing.

Rowe, William L. 1962. The meaning of'God'in Tillich's theology. The Journal of Religion 42 (4): 274-286.

Rowe, William L. 1968. Religious symbols and god: A philosophical study of Tillich's theology. Chicago: University of Chicago Press.

Sahota, Parminder Singh, Maurizio Sajeva, Mark Lemon, and Mehar Brar. 2016. Learning from the Sikh gurus: Improved decision making for more sustainable futures. Philosophy of Management 15 (1): 21-34. https://doi.org/10.1007/s40926-016-0030-1.

Schwartz, Mark S. 2006. God as a managerial stakeholder? Journal of Business Ethics 66 (2-3): 291-306.

Seagrave, S. Adam. 2011. Self-ownership vs. divine ownership: A Lockean solution to a Liberal democratic dilemma. American Journal of Political Science 55 (3): 710-723. https://doi.org/10.1111/j.15405907.2010.00496.x.

Spiro, Melford E. 1966. Religion: Problems of definition and explanation. In Anthropological approaches to the study of religion, ed. Michael Banton, 85-96.

Starik, Mark. 1995. Should trees have managerial standing? Toward stakeholder status for non-human nature. Journal of Business Ethics 14 (3): 207-217.

Stark, Rodney, Laurence R. Iannaccone, and Roger Finke. 1996. Religion, science, and rationality. The American Economic Review 86 (2): 433-437.

Tam, Stanley. 2013. God owns my business: They said it Couldn't be done. But Formally and Legally: Moody Publishers. Taylor, Charles. 2007. A secular age. Harvard University Press.

Tillich, Paul. 1957. Dynamics of faith. New York: Harper.

Torry, Malcolm. 2017. Managing God's business: Religious and faith-based organizations and their management. Routledge.

Van Duzer, Jeff. 2010. Why business matters to God: (And what still needs to be fixed). InterVarsity Press.

Voskuil, Duane. 2016. Proc and dipolar reality: An essay in process, event metaphysics: Rethinking Whitehead's Categoreal scheme, Process studies. Eugene, OR: Wipf and Stock.

Wilson, Rodney. 2006. Islam and business. Thunderbird International Business Review 48 (1): 109-123.

Young, Simon, and Helen Killick. 2017. Religion and the decline of magic. London: Macat Library.

Publisher's Note Springer Nature remains neutral with regard to jurisdictional claims in published maps and institutional affiliations.

Marian Eabrasu is Associated Professor at the at the European Business School (EBS), Paris / INSEEC U. (France), obtained the Ph.D. in political science in 2007 at the Paris VIII University (France) and the Habilitation in economics and management in 2013 at the Angers University (France). He has previously been research fellow at the International Centre for Economic Research (Italy) and Associated Professor at the South Champagne Business School (France). Marian Eabrasu currently serves as associated and book reviews editor at the Philosophy of Management and his research and teaching interests are at the crossroads of philosophy, management, economics, and political science: Corporate Social Responsibility, business ethics, theories of value and international affairs. The results of his research are available in several international peer-reviewed journals such as Journal of Business Ethics, Politics, Philosophy and Economics, Business and Society Review, etc. Recently he authored the book Moral Disagreements in Business: An Introductory Exploration (Springer, 2018). 